\title{
The Effect of Internal Heat Exchanger Using R1234ze(E) as an Alternative Refrigerant in a Mobile Air-Conditioning System
}

\author{
Mehmet Direk1,** Eren Soylu² \\ 1University of Yalova, Faculty of Engineering, Turkey \\ 2 University of Yalova, Institute of Science and Engineering, Turkey
}

In this study, the use of R1234ze(E) refrigerant in an R134a-based mobile air-conditioning (MAC) system was experimentally investigated. Additionally, the effect of internal heat exchanger (IHX) on the performance of MAC was determined using R1234ze(E). Under the same conditions, we have tested and compared two different cases that use R1234ze(E) with and without an IHX by taking the performance of $R 134 \mathrm{a}$ as a reference. The inlet airflow temperatures of the evaporator and condenser were kept at $27^{\circ} \mathrm{C}$ and $35^{\circ} \mathrm{C}$ during the experiments, respectively. Performance parameters were determined using energy and exergy analysis. Compressor power was reduced by an average of $19 \%$, and the COP of R1234ze(E) were increased by an average of $4 \%$ after activating the IHX. Moreover, it was determined that the value of exergy destruction of the system with R1234ze(E) was decreased by an average of $50 \%$ when compared to R134a.

Keywords: R134a, R1234ze(E), mobile air conditioning, coefficient of performance, internal heat exchanger

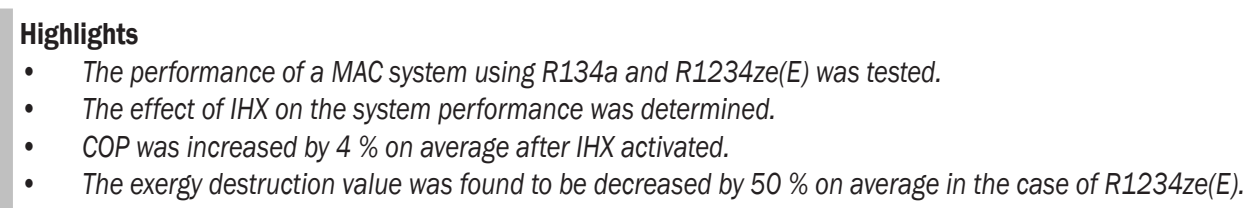

\section{INTRODUCTION}

Even though R134a has low ozone depletion potential (ODP), its global warming potential (GWP) value is as high as 1300 [1]. Therefore, European Regulation No. 2006/40/EC and No. 517/2014 restrict the usage of HFCs which have GWP greater than 150 in MAC systems and other vapour compression refrigeration (VCR) systems [2] and [3]. Aprea et al. [4] experimentally investigated a refrigeration system using R1234ze(E) as a replacement of R134a. Total equivalent warming impact (TEW1) and life cycle climate performance indexes were found to be lower than R134a for all working conditions. In addition to low GWP values, R1234ze(E) has low flammability with regards considering safety issues [5]. Imamura et al. [6], performed experiments to elucidate fire hazards of R32 and R1234ze(E). They observed that ignition could be prevented using mechanical ventilation when the level of leakage is equal to the upper flammability limit (UFL). Table 1 shows that the vapour density of R1234ze(E) is $19 \%$, and the latent heat is $7 \%$ lower when compared to R134a. R1234ze(E) has a low mass flow rate per unit volume of compression and thus a lower cooling capacity. Mota-Babiloni et al. [7] have identified the performance parameters of a refrigeration system, which uses R134a and R1234ze(E), as the functions of different evaporator and condenser temperatures. They observed that the R1234ze(E) has lower cooling capacity and COP values by $30 \%$ and $9 \%$, respectively, in comparison compared to R134a. Leighton et al. [8] tested R1234ze(E) as an alternative to R134a in a refrigeration system. They found that R1234ze(E) has a lower cooling capacity and COP by $21.5 \%$ and $7.9 \%$, respectively.

Table 1. Refrigerant properties of R1234ze(E) and R134a [1] and [9]

\begin{tabular}{lcc}
\hline Property & $\mathrm{R} 134 \mathrm{a}$ & $\mathrm{R} 1234 \mathrm{ze}(\mathrm{E})$ \\
\hline ASHRAE safety classification & $\mathrm{A} 1$ & $\mathrm{~A} 2 \mathrm{~L}$ \\
\hline ODP & 0 & 0 \\
\hline GWP & 1300 & 4 \\
\hline Critical temperature $[\mathrm{K}]$ & 247.08 & 253.88 \\
\hline Critical pressure $[\mathrm{kPa}]$ & 4059.28 & 3623.90 \\
\hline Vapor density $[\mathrm{kg} \cdot \mathrm{m}-3]$ & 14.35 & 11.65 \\
\hline Liquid density $\left[\mathrm{kg} \cdot \mathrm{m}^{-3}\right]$ & 1295 & 1240 \\
\hline Latent heat of vaporization $\left[\mathrm{kJ}^{-} \mathrm{kg}^{-1}\right]$ & 198.72 & 184.28 \\
\hline
\end{tabular}

Janković et al. [10] carried out a study in a VCR system and found that the cooling capacity of $\mathrm{R} 1234 \mathrm{ze}(\mathrm{E})$ is $27 \%$ lower, and the COP value is similar to that of R134a. They also observed that at higher compressor speeds, R1234ze(E) provides the same cooling capacity with R134a at the rates of $34 \%$ to $39 \%$. Kabeel et al. [11] figured out the performance of the VCR cycle for the cases of R134a and R1234ze(E). They found that the R1234ze(E) 
has lower cooling capacity and compressor power by $2 \%$ to $13 \%$ and $9 \%$ to $15 \%$, respectively. Righetti et al. [12] conducted performance analysis of a rollbond evaporator for household refrigerators using R1234yf, R1234ze(E) and R600a and tested similar vaporization performance from the refrigerants. They concluded that these refrigerants could be considered as alternatives to R134a when they have similar mass flow rates. Sethi et al. [13], conducted a performance evaluation of two different refrigerants having low GWP, R1234yf and R1234ze(E), as substitutes for R134a. When the larger compressor displacement is used, R1234ze(E) performed similarly to R134a.

Mastrullo et al. [14] built a simulation model to assess the evolvement of the temperature inside a train compartment. They found that COP of the R1234ze(E) is $16 \%$ higher than the case of R134a. Majurin et al. [15] were conducted research to figure the material compatibility exposures using R1234yf, R1234ze(E), and a mixture of R1234yf, R1234ze(E), and R32.

The performance of the VCR cycle can be increased by introducing an IHX into the liquid and gas suction line. The IHX increases the value of the sub-cooling at the condenser outlet, and thus raises the enthalpy difference in the evaporator and enhances the cooling capacity [16]. Cho and Park [17] determined the performance of an experimental automotive air-conditioning system for the cases of R134a and R1234yf refrigerant utilization. They found that when the IHX is used in the system, the cooling capacity of R1234yf was enhanced by $0.9 \%$ compared to that of R134a at $2500 \mathrm{rpm}$. Furthermore, they determined that the amount of exergy destruction in the compressor is higher than that of the evaporator, after increasing the speed of the compressor. Direk et al. [18] investigated the effects of a double-pipe IHX added to the system on the performance parameters in an automobile air conditioning system using R1234yf. They stated that the contribution of the IHX to the COP is reduced by increasing the temperatures of the airflow entering the evaporator and the condenser. Babiloni et al. [7] found that R1234ze(E) provides the same cooling capacity values as R134a at $36 \%$ higher compressor speed or geometric volume. They also found that the mass flow rate of R1234ze(E) was $5 \%$ higher than R134a when it was operated at $43 \%$ higher compressor speeds. As a result, they have determined that the difference in cooling capacity compared to R134a can be reduced by up to $20 \%$ when R1234ze(E) is used with an IHX. Researchers in the literature use different types of heat exchangers for better system performance as they contribute to effective and more efficient functioning of the system [19]. Due to their high overall heat- transfer coefficient and compactness, plate type heat exchangers have recently gained more attention [20]. Such exchangers can be used instead of double-pipe heat exchangers as the IHX in the cooling systems. Devecioğlu and Oruç [21] investigated the effects of a plate-type heat exchanger in the liquid and gas suction line, on the system performance of an air conditioner using R453a, as an alternative to R22. They have found that the COP value obtained with R453a is lower than that of R22. However, there was a significant improvement in the COP value with the use of the IHX.

Jemaa et al. [22] theoretically investigated a VCR system using R1234ze(E) as an alternative to R134a under different evaporator and ambient temperatures. They determined that the irreversibility was lower in case of R1234ze(E). Yataganbaba et al. [23] developed a theoretical model to calculate the exergetic performance of the two evaporator VCR system using R1234yf and R1234ze(E) as alternatives to R134a. They determined that the second law efficiency of the system with R1234ze(E) and R134a is higher than that of R1234yf. Perez-Garcia et al. [24] conducted a second law analysis of the MAC system with IHX using R152a, R1234yf, and R1234ze(E). They determined that second law efficiency was the highest for R1234ze(E) when the superheating degree effect is increased.

To the best of our knowledge, this is the first experimental demonstration of drop in performance of R1234ze(E) in an R134a-based MAC system under various compressor speeds. In this research, the experimental setup was employed with on and off valves to activate liquid and gas section line IHX. The influence of energy and exergy performance of a plate-type IHX was extensively evaluated, and the exergy destruction in the components of the system was investigated. System performance parameters were realized, considering various compressor speeds, and the results were presented comparatively.

\section{THERMODYNAMIC ANALYSIS}

Fig. 1 shows the paths that the refrigerant follows within the system. The refrigerant follows the path of 1-2-3-4-5 when the IHX is inactive and follows the path of 1'-2'-3'-4'-5' when it is active.

Energy analysis was done by applying the first law of thermodynamics to each component of the MAC system. The exergy analysis was performed employing the second law of thermodynamics. Accordingly, the energy analysis for a steady-state system can be evaluated by: 


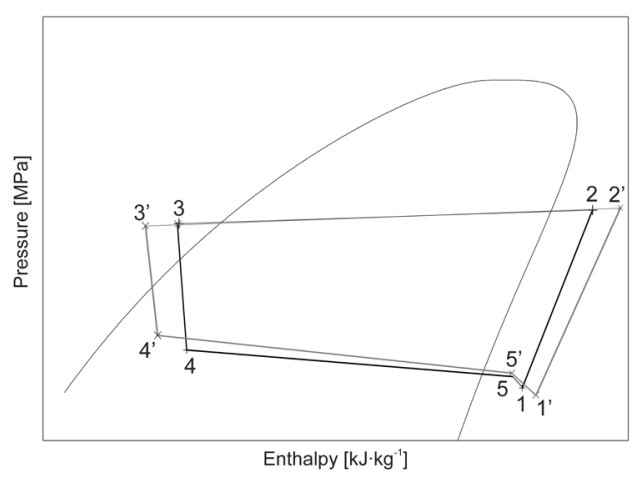

Fig. 1. P-h diagram of the system with and without IHX

$$
\dot{Q}_{C V}-\dot{W}_{C V}=\sum \dot{m}_{i} h_{i}-\sum \dot{m}_{o} h_{o} .
$$

The exergy analysis for a steady-state system was calculated by:

$$
\begin{gathered}
\dot{E} x_{d}=\sum\left(1-\frac{T_{0}}{T}\right) \dot{Q}-\sum \dot{W}+\sum_{i} \dot{m} \psi-\sum_{o} \dot{m} \psi, \\
\psi=\left(h-h_{0}\right)-T_{0}\left(\mathrm{~s}-s_{0}\right) .
\end{gathered}
$$

Assuming no heat loss from the compressor, the energy and exergy values can be obtained using:

$$
\begin{gathered}
\dot{W}_{\text {comp }}=\dot{m}_{r}\left(h_{2}-h_{1}\right), \\
\dot{E}_{d, \text { comp }}=\dot{m}_{r}\left(\psi_{1}-\psi_{2}\right)+\dot{W}_{\text {comp }} .
\end{gathered}
$$

The exergy destruction rate of the thermostatic expansion valve (TXV) can be calculated from:

$$
\dot{E} x_{d, T X V}=\dot{m}_{r}\left(\psi_{3}-\psi_{4}\right)=\dot{m}_{r} T_{0}\left(s_{4}-s_{3}\right) .
$$

The energy and exergy analysis of the evaporator and condenser can be expressed as:

$$
\begin{gathered}
\dot{Q}_{\text {evap }}=\dot{m}_{r}\left(h_{4}-h_{1}\right), \\
\dot{E} x_{d, \text { evap }}=\dot{m}_{r}\left(\psi_{1}-\psi_{4}\right)+\dot{Q}\left(1-\frac{T_{0}}{T_{\text {evap }}}\right), \\
\dot{Q}_{\text {cond }}=\dot{m}_{r}\left(h_{3}-h_{2}\right), \\
\dot{E} x_{d, \text { cond }}=\dot{m}_{r}\left(\psi_{2}-\psi_{3}\right)-\dot{Q}\left(1-\frac{T_{0}}{T_{\text {cond }}}\right) .
\end{gathered}
$$

The energy and exergy destruction rate for the IHX can be determined from:

$$
\begin{array}{r}
h_{i, I H X, \text { evap }}+h_{i, I H X, \text { cond }}=h_{o, I H X, \text { evap }}+h_{o, I H X, \text { cond }}, \\
\dot{E} x_{d, I H X}=\dot{m}_{r}\left(\psi_{i, I H X, \text { evap }}-\psi_{o, I H X, \text { evap }}\right) \\
+\dot{m}_{r}\left(\psi_{i, I H X, \text { cond }}+\psi_{o, I H X, \text { cond }}\right) .
\end{array}
$$

The COP of the MAC system can be obtained from:

$$
C O P=\dot{Q}_{\text {evap }} / \dot{W}_{\text {comp }}
$$

The total exergy destruction rate for the MAC system can be obtained from:

$$
\begin{aligned}
\dot{E} x_{d, t}= & \dot{E} x_{d, \text { comp }}+\dot{E} x_{d, \text { cond }}+\dot{E} x_{d, T X V} \\
& +\dot{E} x_{d, \text { evap }}+\dot{E} x_{d, I H X} .
\end{aligned}
$$

\section{EXPERIMENTAL SETUP}

The experimental system consists of the components of a VCR system used in MAC systems. This system, which is schematically shown in Fig. 2, consists of a swash-plate type compressor, a parallel-flow condenser, a laminar type evaporator, a thermostatic expansion valve and a liquid tank. In addition, a platetype heat exchanger was introduced to the liquid and gas suction lines of the system to provide heat to the fluid stream exiting the evaporator in the vapour phase.

In the experimental MAC system used, the refrigerant is converted into superheated vapour at high pressure and temperature in the compressor and sent to the condenser. It is condensed through the air flow and exits the condenser in a phase of compressed liquid at high pressure.

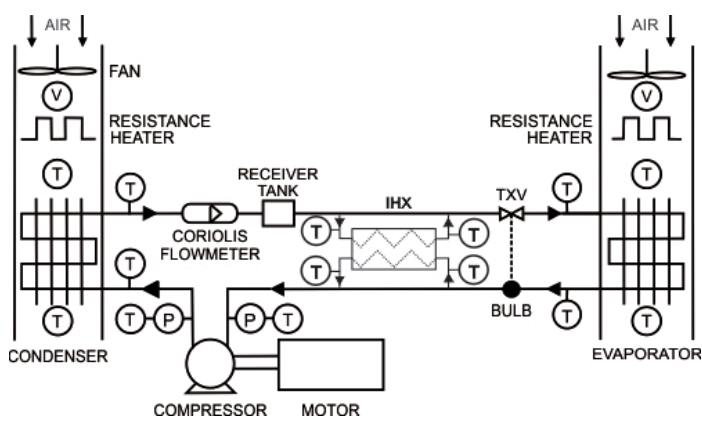

Fig. 2. Schematic diagram of the experimental setup

Afterwards, the refrigerant, which enters the IHX, transfers heat to the fluid stream that is in a vapour phase, which exits the evaporator and enters the IHX. The refrigerant in the liquid phase then passes through the liquid tank and through the Coriolis-type mass flow meter. Afterwards, the refrigerant flows to the TXV, and it arrives the evaporator as a liquidvapour phase at low pressure after its pressure and temperature are decreased in TXV in such a way that the superheat at the outlet of the evaporator remains constant. The heat-loaded refrigerant, which exits the 
evaporator, is directed to the IHX and finally to the compressor inlet and completes its cycle.

Electric heaters were installed to provide the desired airflow temperatures in the evaporator and condenser ducts, and the fans were installed to provide the airflow to the inlet of the air ducts at the desired speed. Copper tubes were used for the steam and liquid lines as connection elements. The connecting elements were isolated with elastomeric isolation material. The components of the experimental system are presented in Table 2 .

Table 2. Specifications of components MAC system

\begin{tabular}{|c|c|}
\hline Components & Specifications \\
\hline Compressor & $\begin{array}{l}\text { Swash-plate type } 138 \text { cc } \\
\text { Number of Cylinders: } 5\end{array}$ \\
\hline Condenser & $(580 \times 350 \times 20) \mathrm{mm}^{3}$ \\
\hline Evaporator & $(220 \times 260 \times 60) \mathrm{mm}^{3}$ \\
\hline Expansion valve & TXV (Internally equalized with bulb 5.27 kW) \\
\hline $\begin{array}{l}\text { Internal heat } \\
\text { exchanger }\end{array}$ & $\begin{array}{l}(192 \times 73 \times 63) \mathrm{mm}^{3} \\
\text { Type: Brazed plate } \\
\text { Number of plates: } 24 \\
\text { Heat transfer area: } 0.6 \mathrm{~m}^{2}\end{array}$ \\
\hline
\end{tabular}

The system was equipped with various measuring instruments. The temperatures of the refrigerant were measured at the inlet and outlet points of each component using K-type thermocouples. The measured values were transferred to the computer via the data acquisition system.

The pressure measurements for evaporation and condensation were carried out by using a digital manifold at four points in the system. The mass flow rate of the refrigerant was measured with a Coriolistype flow meter. The precisions of the measuring devices are presented in Table 3. A frequency inverter was used to set the compressor speed with a $2.2 \mathrm{~kW}$ electric motor.

Table 3. Specifications of the instrumentation

\begin{tabular}{|c|c|c|c|}
\hline Measurement & Device & Range & Precision \\
\hline Temperature & $\begin{array}{l}\text { K-type } \\
\text { Thermocouple }\end{array}$ & $-100^{\circ} \mathrm{C}$ to $1370^{\circ} \mathrm{C}$ & $\pm 0.8^{\circ} \mathrm{C}$ \\
\hline Pressure & $\begin{array}{l}\text { Electronic } \\
\text { Manifold }\end{array}$ & -1 bar to 60 bar & $\pm 0.5 \%$ \\
\hline Air Flow Rate & Anemometer & $0 \mathrm{~ms}^{-1}$ to $30 \mathrm{~ms}^{-1}$ & $\pm 2 \%$ \\
\hline $\begin{array}{l}\text { Refrigerant } \\
\text { Mass Flow Rate } \\
\end{array}$ & $\begin{array}{l}\text { Coriolis Mass } \\
\text { Flow Meter }\end{array}$ & $0 \mathrm{~kg} \mathrm{~s}^{-1}$ to $5 \mathrm{~kg} \mathrm{~s}^{-1}$ & $\pm 0.1 \%$ \\
\hline Power & Clamp Meter & $0 \mathrm{~kW}$ to $600 \mathrm{~kW}$ & $\pm 2 \%$ \\
\hline $\begin{array}{l}\text { Compressor } \\
\text { Speed }\end{array}$ & $\begin{array}{l}\text { Frequency } \\
\text { inverter }\end{array}$ & $10 \mathrm{~Hz}$ to $50 \mathrm{~Hz}$ & $\pm 0.2 \%$ \\
\hline
\end{tabular}

The thermophysical properties of the refrigerant are taken from the REFPROP 9.1 program [9].
The charge amount of R134a in the system was determined when the system achieved the best COP. To provide mass equivalence in the system, the charge amount was calculated by using liquid densities. In the experimental study, $600 \mathrm{~g}$ of R134a and $625 \mathrm{~g}$ of R1234ze(E) refrigerant were charged into the system, in accordance with the liquid density of refrigerant presented in Table 1 . In the experiments, the temperatures of the airflow entering the evaporator and condenser were kept constant at $27{ }^{\circ} \mathrm{C}$ and $35^{\circ} \mathrm{C}$, respectively. Experiments were carried out by changing the speed of the compressor between $750 \mathrm{rpm}$ and $2750 \mathrm{rpm}$ by $500 \mathrm{rpm}$ increment intervals. During the experiments, the measurements were done after the system was stabilized. During the experiments, the electric heaters were run to regulate the air stream temperatures at the inlet of the evaporator and condenser. The main data used for measuring the performance of the cycle are temperature, pressure and refrigerant mass flow rate. With presented precision values in Table 3, the calculated uncertainty rates for the cooling capacity, COP and compressor power were $\pm 2.99 \% \pm 4.4 \%$, and $\pm 3.24 \%$, respectively.

\section{RESULTS AND DISCUSSION}

In this section, the performance parameters of the system are discussed considering the effect of IHX for $\mathrm{R} 1234 z \mathrm{z}(\mathrm{E})$. The superheat and sub-cooling degrees of the system are the best ways to show the IHX effect on the cooling cycle. Table 4 shows the experimental superheat and sub-cooling degrees for various compressor speeds and configurations of the system.

Table 4. Superheat and sub-cooling values of each configuration

\begin{tabular}{ccccc}
\hline & $\begin{array}{c}\text { Compressor } \\
\text { speed [rpm] }\end{array}$ & R134a & R1234ze(E) & $\begin{array}{c}\text { R1234ze(E)+ } \\
\text { IHX }\end{array}$ \\
\cline { 2 - 5 } & 750 & 5.2 & 6.14 & 10.26 \\
\cline { 2 - 5 } Superheat & 1250 & 7.5 & 10.66 & 15.65 \\
\cline { 2 - 5 }$\left[{ }^{\circ} \mathrm{C}\right]$ & 1750 & 10.2 & 13.92 & 20.01 \\
\cline { 2 - 5 } & 2250 & 12.7 & 20.75 & 24.82 \\
\cline { 2 - 5 } & 2750 & 15.6 & 22.86 & 29.38 \\
\hline \multirow{3}{*}{$\begin{array}{c}\text { Sub- } \\
\text { cooling } \\
{\left[{ }^{\circ} \mathrm{C}\right]}\end{array}$} & 150 & 5.77 & 8.51 & 12.01 \\
\cline { 2 - 5 } & 1750 & 7.08 & 12.46 & 16.70 \\
\cline { 2 - 5 } & 2250 & 10.81 & 14.45 & 20.44 \\
\hline
\end{tabular}

It is understood from Table 4 that by adapting the IHX to the system, both the superheat and sub-cooling degree were increased. The increased sub-cooling degree improves the cooling capacity by increasing 
the latent heat of vaporization of the refrigerant. However, the exergy destruction in the compressor increased by increasing the superheat value.

Fig. 3 represents the change in compressor power as a function of compressor speed. The vapour density of R1234ze(E) is lower than R134a, as seen in Table 1. Thus, the experimental results indicate that the mass flow rate of R134a is $17 \%$ higher than that of R1234ze(E). This results in the higher compression power demands for R134a compared to R1234ze(E). When the IHX is adapted to the system, it increased the superheat value for R1234ze(E), as seen in Table 4.

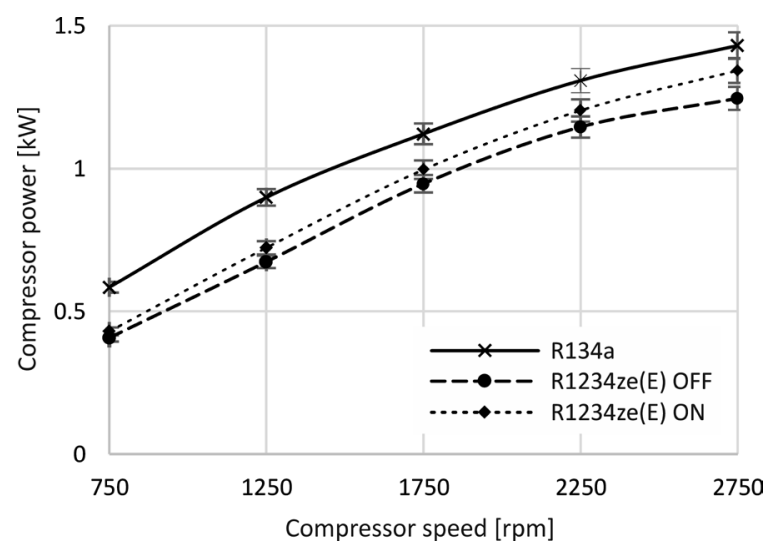

Fig. 3. Compressor power versus compressor speed

Considering the changes caused by the addition of IHX, the suction pressure of the compressor was reduced, and the value of superheat was increased; thus, the compression ratio was increased accordingly. As a result, the compressor power was enhanced by adapting IHX to the system.

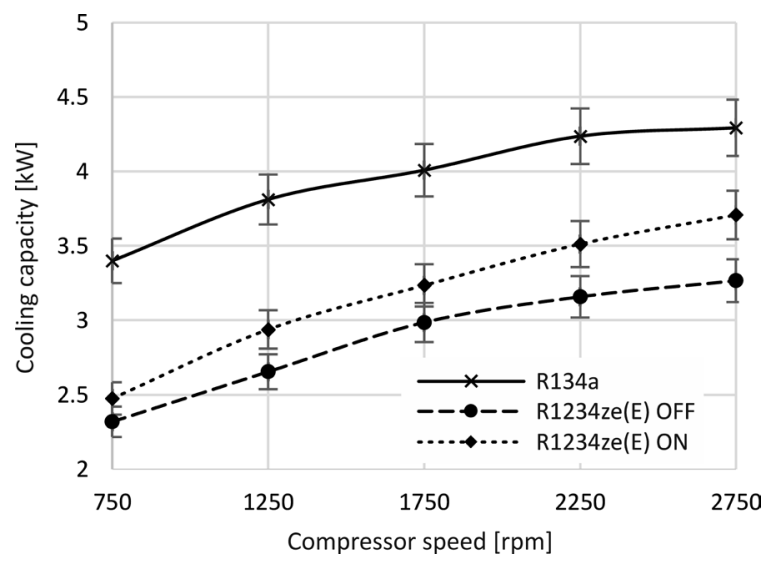

Fig. 4. Cooling capacity versus compressor speed

Fig. 4 demonstrates the cooling capacity for all configurations as a function of compressor speed.
R1234ze(E) has $7 \%$ lower latent heat of vaporization compared to R134a, which leads to lower cooling capacity at the same evaporation pressure. However, the IHX enhances latent heat by boosting the subcooling values. R1234ze(E) has an average $27 \%$ lower cooling capacity as seen in Fig. 4. In addition, the cooling capacity was increased by $7 \%$ after the IHX was introduced. The IHX enhances the value of the sub-cooling at the condenser outlet as depicted in Fig. 1. Table 4 also indicates that the amount of sub-cooling increases due to the compressor speed. Consequently, the amount of sub-cooling directly affects the enthalpy difference in the evaporator and thus, the cooling capacity improves.

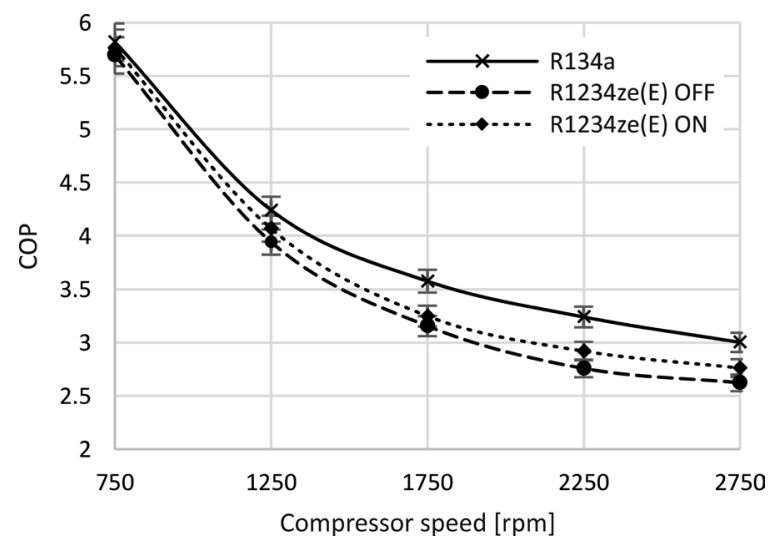

Fig. 5. COP versus compressor speed

The changes in COP depending on the compressor speed are presented in Fig. 5. It can be seen that the COP obtained at all compressor speeds for $\mathrm{R} 1234 \mathrm{ze}(\mathrm{E})$ on the refrigerant is lower than that of R134a. However, COP of R1234ze(E) is very close to R134a at lower compressor speeds. Furthermore, the difference become lower when IHX was introduced into the system. An increase in the COP of R1234ze(E) was observed after the IHX was adapted. COP was increased by $4 \%$ on average after the activation of IHX.

The exergy destruction of the system for different configurations is given in Fig. 6. It can be seen that the values of exergy destruction for R1234ze(E) are lower than that of R134a, regardless of the presence of IHX. The exergy destruction for all configurations was increased by increasing the compressor speed. In addition, the exergy destruction was increased by introducing IHX to the system with R1234ze(E). This is considered to be due to the increase in exergy destruction in the compressor and the exergy destruction inside the IHX at increasing compressor speeds. 


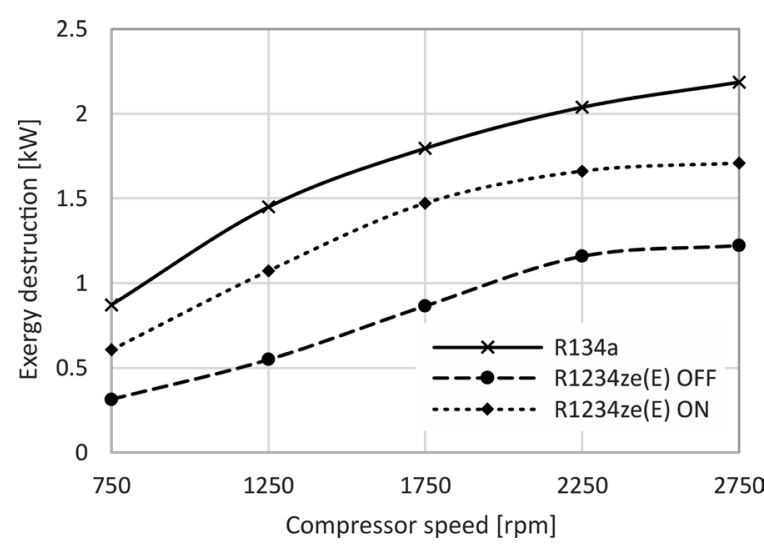

Fig. 6. Exergy destruction versus compressor speed

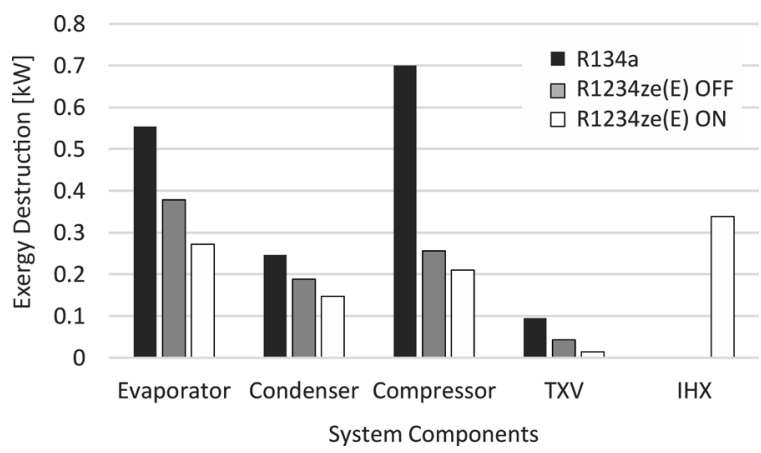

Fig. 7. Equipment-based distribution of exergy destruction at 1750 rpm

The equipment-based distribution of exergy destruction values at $1750 \mathrm{rpm}$ are shown in Fig. 7. It should be noted that the exergy destruction values are decreased in the condenser, evaporator, and TXV, but increased in the compressor by employing the IHX. Moreover, introducing an IHX to the system leads to a certain amount of exergy destruction.

\section{CONCLUSIONS}

In this study, the usage of R1234ze(E) in an R134a-based MAC system was experimentally investigated. Additionally, the effect of the IHX, on the performance of the MAC system was determined by using R1234ze(E). The results of the study and the evaluations are presented below.

The compressor power for R1234ze(E) was lower than that of R134a by $19 \%$, but the difference became lower $(14 \%)$ when IHX was introduced into the system. The cooling capacity was lower for R1234ze(E) than R134a by $27 \%$. The cooling capacity was improved by $7 \%$ when IHX was adapted.

The COP of R1234ze(E) was lower than that of R134a by $8 \%$ to $10 \%$. The COP value was enhanced by $4 \%$ when IHX was adapted to the system. The exergy destructions of R1234ze(E) were lower than R134a by $50 \%$, and this became lower by $25 \%$ on average when IHX was adapted to the system.

In light of these results, it is considered that R1234ze(E) might be an alternative refrigerant suitable for MAC applications if necessary amendments are carried out.

\section{ACKNOWLEDGEMENTS}

The authors would like to thank the Scientific and Technological Research Council of Turkey (TÜBITAK) for supporting this study through Research Project No 216M437.

\section{NOMENCLATURE}

$\begin{array}{ll}\dot{Q} & \text { heat transfer, }[\mathrm{kW}] \\ \dot{W} & \text { work, }[\mathrm{kW}] \\ \dot{m} & \text { mass flow rate, }\left[\mathrm{kg} \cdot \mathrm{s}^{-1}\right] \\ h & \text { enthalpy, }\left[\mathrm{kJ} \cdot \mathrm{kg}^{-1}\right] \\ \dot{E} x & \text { exergy destruction, }[\mathrm{kW}] \\ T & \text { temperature, }[\mathrm{K}] \\ s & \text { entropy, }\left[\mathrm{kJ} \cdot \mathrm{kg}^{-1} \cdot \mathrm{K}^{-1}\right] \\ \psi & \text { flow specific exergy, }\left[\mathrm{kJ} \cdot \mathrm{kg}^{-1}\right]\end{array}$

Subscripts:

$\begin{array}{ll}\text { comp } & \text { compressor, } \\ \text { cond } & \text { condenser, } \\ C V & \text { control volume, } \\ e & \text { electrical, } \\ \text { evap } & \text { evaporator, } \\ \text { ex } & \text { exergy, } \\ d & \text { destruction, } \\ i & \text { inlet, } \\ o & \text { outlet, } \\ r & \text { refrigerant, } \\ t & \text { total, } \\ 0 & \text { dead state. }\end{array}$

\section{REFERENCES}

[1] Hartmann, D.L., Klein Tank, A.M.G.,Rusticucci, M.,Alexander, L.V., Brönnimann, S., Charabi, Y., Dentener, F.J., Dlugokencky, E.J., Easterling, D.R., Kaplan, A., Soden, B.J., Thorne, P.W., Wild, M., Zhai, P.M. (2013). Observations: Atmosphere and Surface. Stocker, T.F., Qin, D., Plattner, G-K., Tignor, M., Allen, S.K., Boschung, J., Nauels, A., Xia, Y., Bex, V., Midgley, P.M. (eds.), Climate Change 2013: The Physical Science Basis. Cambridge University Press, Cambridge, p. 159-254, D0l:10.1017/CB09781107415324.008.

[2] Directive 2006/40/EC of the European Parliament and of the Council of 17 May 2006 Relating to Emissions from Air 
Conditioning Systems in Motor Vehicles and Amending Council Directive 70/156/EC (2006). Official Journal of the European Union, Brussels.

[3] Regulation (EU) No 517/2014 of the European Parliament and the Council of 16 April 2014 on Fluorinated Greenhouse Gases and Repealing Regulation (EC) No 842/2006 (2014). Official Journal of the European Union, Brussels.

[4] Aprea, C., Greco, A., Maiorino, A., Masselli, C., Metallo, A. (2016). HF01234ze as drop-in replacement for R134a in domestic refrigerators: An environmental impact analysis. Energy Procedia, vol. 101, p. 964-971, D0l:10.1016/j. egypro.2016.11.122.

[5] ASHRAE Standard 34 (2013). Designation and Safety Classification of Refrigerants. American Society of Heating, Refrigerating and Air-Conditioning Engineers, Atlanta.

[6] Imamura, T., Yoshida, Y., Ota, Y., Naito, K., Sugawa, O. (2017). Full-scale experiment to evaluate the combustion hazard of refrigerants with low global-warming potential in a conceivable accident scenario. International Journal of Refrigeration, vol. 82, p. 461-469, D0l:10.1016/j.jirefrig.2017.06.004.

[7] Mota-Babiloni, A., Navarro-Esbrí, J., Mendoza-Miranda, J. M., \& Peris, B. (2017). Experimental evaluation of system modifications to increase R1234ze(E) cooling capacity. Applied Thermal Engineering, vol. 111, p. 786-792, DOI:10.1016/J.applthermaleng.2016.09.175.

[8] Leighton, D., Hwang, Y., Radermacher, R. (2012). Modeling of household refrigerator performance with low global warming potential alternative refrigerants. ASHRAE Transactions, vol. 118 , p. 658.

[9] Lemmon, E.W., Huber, M.L., McLinden, M.O. (2014). REFPROP, NIST Standard Reference.

[10] Janković, Z., Atienza, J.S., Suárez, J.A.M. (2015). Thermodynamic and heat transfer analyses for R1234yf and R1234ze(E) as drop-in replacements for R134a in a small power refrigerating system. Applied Thermal Engineering, vol. 80, p. 42-54, D0l:10.1016/J.applthermaleng.2015.01.041.

[11] Kabeel, A.E., Khalil, A., Bassuoni, M.M., Raslan, M.S. (2016). Comparative experimental study of low GWP alternative for R134a in a walk-in cold room. International Journal of Refrigeration, vol. 69, p. 303-312, D0l:10.1016/j. ijrefrig.2016.06.017.

[12] Righetti, G., Zilio, C., Giovanni, A.L. (2015). Comparative performance analysis of the low GWP refrigerants HF01234yf, HF01234ze(E) and HC600a inside a roll-bond evaporator. International Journal of Refrigeration, vol. 54, p. 1-9, DOI:10.1016/j.jjrefrig.2015.02.010.

[13] Sethi, A., Vera-Becerra, E., Yana-Motta, S. (2016). Low GWP R134a replacements for small refrigeration (plug-in) applications. International Journal of Refrigeration, vol. 66, p. 64-72, D0I:10.1016/j.jijrefrig.2016.02.005.

[14] Mastrullo, R., Mauro, A.W., Vellucci, C. (2016). Refrigerant alternatives for high speed train $\mathrm{A} / \mathrm{C}$ systems: energy savings and environmental emissions evaluation under variable ambient conditions. Energy Procedia, vol. 101, p. 280-287, DOI:10.1016/j.egypro.2016.11.036.

[15] Majurin, J., Staats, S.J., Sorenson, E., Gilles, W. (2015). Material compatibility of HVAC\&R system materials with low global warming potential refrigerants. Science and Technology for the Built Environment, vol. 21, p. 491-501, D0I:10.1080/2 3744731.2015.1009353.

[16] Klein, S.A., Reindl, D.T., Brownell, K. (2000). Refrigeration system performance using liquid-suction heat exchangers. International Journal of Refrigeration, vol. 23, no. 8, p. 588596, DOI:10.1016/S0140-7007(00)00008-6.

[17] Cho, H., Park, C. (2016). Experimental investigation of performance and exergy analysis of automotive air conditioning systems using refrigerant R1234yf at various compressor speeds. Applied Thermal Engineering, vol. 101, p. 30-37, D0I:10.1016/j.applthermaleng.2016.01.153.

[18] Direk, M., Kelesoglu, A., Akin, A. (2017). Drop-in performance analysis and effect of $\mathrm{IHX}$ for an automotive air conditioning system with R1234yf as a replacement of R134a. Strojniški vestnik-Journal of Mechanical Engineering, vol. 63, no. 5, p. 314-319, D0I:10.5545/sv-jme.2016.4247.

[19] Bošnjaković, M., Čikić, A., Muhič, S., Stojkov, M. (2017). Development of a new type of finned heat exchanger. Tehnički vjesnik - Technical Gazette, vol. 24, no. 6, p. 1785-1796, DOI:10.17559/TV-20171011071711.

[20] Pribošek, J., Bobič, M., Golobič, I., Diaci, J. (2016). Correcting the Periodic Optical Distortion for Particle-Tracking Velocimetry in Corrugated-Plate Heat Exchangers. Strojniški vestnik Journal of Mechanical Engineering, vol. 62 no. 1, p. 3-10, DOI:10.5545/sv-jme.2015.3125.

[21] Devecioğlu, A.G., Oruç, V. (2017). The influence of platetype heat exchanger on energy efficiency and environmental effects of the air-conditionersa using R453A as a substitute for R22. Applied Thermal Engineering, vol. 112, p. 13641372, DOI:10.1016/j.applthermaleng.2016.10.180.

[22] Jemaa, R.B., Mansouri, R., Boukholda, I., Bellagi, A. (2017). Energy and exergy investigation of R1234ze as R134a replacement in vapor compression chillers. International Journal of Hydrogen Energy, vol. 42, no. 17, p. 12877-12887, D0I:10.1016/j.ijhydene.2016.12.010.

[23] Yataganbaba, A., Kilicarslan, A., Kurtbas, I. (2015). Exergy analysis of R1234yf and R1234ze as R134a replacements in a two evaporator vapor compression refrigeration system. International Journal of Refrigeration, vol. 60, p. 26-37, D0l:10.1016/j.jjrefrig.2015.08.010.

[24] Pérez-García, V., Belman-Flores, J.M., Rodríguez-Mu-oz, J.L., Rangel-Hernández, V.H., Gallegos-Mu-oz, A. (2017). Second law analysis of a mobile air conditioning system with internal heat exchanger using low GWP refrigerants. Entropy, vol. 19, no. 4, p. 175, Dol:10.3390/e19040175. 